\title{
KUUNTELEMINEN KESKUSTELUSSA - YHDYSVALTALAISEN JA SUOMALAISEN AINEISTON VERTAILU
}

Tuula-Riitta Välikoski, FT, HM, logonomi

Pubeopin laitos, Tampereen yliopisto

Irma Ilomäki, FM, logonomi

Puheopin laitos, Tampereen yliopisto

Elinita Mäki, YTM, logonomi

Puheopin laitos, Tampereen yliopisto

Laura A. Janusik, PhD.

Department of Communication and Fine Arts, University of Rockburst

\section{TIIVISTELMÄ}

Keskustelukuuntelun aikajännemittari (Conversational Listening Span, CLS) mittaa kokeellisesti henkilöiden keskustelukuuntelemisen kapasiteettia. Kyseinen kapasiteetti tarkoittaa niiden kognitiivisten merkityksien määrää, joita joku kykenee pitämään aktiivisena muistissaan ja joihin hän pystyy vastaamaan keskustelun kuluessa. Keskustelukuuntelun aikajännemittari tarjoaa puheviestintätutkimukseen uuden näkökulman: se mittaa kuuntelemisen prosessia, kun aiemmat mittarit ovat perustuneet esimerkiksi itsearviointiin tai toisen henkilön arviointiin jonkun kuuntelusta. Artikkeli esittelee mittarin ja testaa sen toimivuutta eri kieli- ja kulttuurisessa ympäristössä; Yhdysvalloissa ja Suomessa. Päätuloksia ovat seuraavat: Kiinnostuneisuus aihealueesta ei vaikuta pistemääriin kummassakaan kulttuurissa, eli myös uusi suomenkielinen keskustelukuuntelun aikajännemittari mittaa kuuntelukapasiteettia eikä kiinnostuneisuutta. Yhdysvalloissa käytetty englanninkielinen CLS korreloi Speaking spanin (vertailutestinä käytetty perinteinen työmuistitesti) kanssa, mutta suomenkielinen puhumisen aikajännemittari (Speaking span) ei. Yhdysvaltalaisen ja suomalaisen CLS-testin pisteet olivat kuitenkin hyvin yhtenevät (eli CLS mittaa kuuntelukapasiteettia eri kulttuureissa yhtenevästi), ja siis myös suomenkielinen keskustelukuuntelun aikajännemittari näyttää jo lupaavalta keskustelukuuntelemisen mittarilta.

Asiasanat: aikajännemittari, keskustelukuntelemisen kapasiteetti, kulttuurien välisyys, kunteleminen, työmuisti

\section{JOHDANTO}

Kuunteleminen on määritelty Yhdysvalloissa yhdeksi kansalaisten olennaisis- 
ta perustaidoista yhdessä lukemisen, kirjoittamisen, puhumisen ja matemaattisen perusosaamisen kanssa (Janusik 2004). Tutkimuksissa on todettu että yhdysvaltalaiset yliopisto-opiskelijat käyttävät enemmän aikaa kuunteluun kuin puhumiseen, kirjoittamiseen ja lukemiseen (Barker, Edwards, Gaines, Gladney \& Holley 1980; Davis 2001). Myös Suomessa on alettu ymmärtää kuuntelemisen merkitystä yhteiskunnallisessa toiminnassa, mutta vasta viime vuosina se on kirjattu näkyviin esimerkiksi työyhteisöjen toimintaa ja hyvinvointia kuvaaviin säädöksiin (mm. Työturvallisuuslaki 738/2002; \10) ja määräyksiin (mm. yliopiston uusi palkkausjärjestelmä). Sen sijaan hallinto- ja oikeuskontekstissa kuunteleminen ilmiönä, esimerkiksi oikeus tulla kuulluksi, on ollut kirjattuna kansalaisten perusoikeutena jo pitkään erilaisissa säädöksissä (mm. Suomen Hallitusmuoto 94/1919; \10 perusoikeudet ja Hallintolaki 434/2004).

Kuuntelemisen merkitys yleensä ja kuuntelemisen taidot erityisesti on todettu tärkeiksi sosiaalisiksi taidoiksi sekä yksityis- että työelämässä niin Yhdysvalloissa (Goby \& Lewis 2000; Steil 1997; Wolvin \& Coakley 2000) kuin Suomessa (Mikkola 2000; Tiuraniemi 2004; Valkonen \& Mikkola 2000; Välikoski 2000; 2004; Janusik, Ilomäki, Mäki \& Välikoski 2004). Kuuntelemisen tutkimus osana puheviestintätaitoja on ollut melko vähäistä. Tutkimusta on pääasiassa tehty kuunteluinstrumenteilla, jotka mittaavat toisten havainnointia jonkun kuuntelemisesta, mikä pohjautuu ulospäin näkyviin kuuntelun ilmauksiin, kuten nonverbaaliin viestintään tai verbaaleihin palautteisiin kuullusta. Näin esimerkiksi laajassa puheviestintäkasvatuksen ja -arvioinnin projektissa yläasteen ja lukion oppilaiden puhe- ja ryhmäviestinnän taitoja arvioittiin sekä puhumisen että kuuntelemisen taitojen näkökulmasta, arvioijina oppilaiden omat opettajat (Nyfors 1995; Valkonen 2001). Toisten kuuntelemisen havainnoimisen heikkous on siinä, että mitataan kuuntelemisen tulosta tai tuotetta, havaittavaa käyttäytymistä, ei kuuntelemisen prosessia (Janusik 2003).

Yhdysvalloissa kuuntelemisen tutkimusta on runsaasti (Janusik 2004), mutta näissä tutkimuksissa on usein tutkittu kuuntelemisen lopputulosta tai kehitetty erilaisia malleja jäsentämään kuuntelemiskäyttäytymistä. Myös yhdysvaltalainen kuuntelemisen prosessin tutkimus on suhteellisen nuorta. Tässä tutkimuksessa testataan mittausvälinettä, joka kuvaa yksilön kuuntelemisen kapasiteettia keskustelutilanteissa (Conversational Listening Span, CLS eli keskustelukuuntelun aikajännemittari). Välinettä ovat aiemmin testanneet yhdysvaltalaiset tutkijat (Janusik 2004) ja instrumentti on todettu validiksi. Testin toimivuutta haluttiin nyt laajentaa ja kokeilla sitä erilaisessa kieli- ja kulttuuriympäristössä.

\section{TUTKIMUKSEN TAUSTAA JA TUTKIMUSHYPOTEESIT}

Työmuistin kapasiteetti ja työmuistiteoria. Työmuisti on ajallisesti lyhytkestoinen muistijärjestelmä, jonka tehtävänä on toisaalta tiedon työstäminen ja toisaalta tiedon hetkellinen ylläpitäminen. Työmuistin toiminnan kannalta erityisen 
keskeinen tekijä on kyky ohjata tarkkaavaisuutta tehtävän kannalta järkevällä tavalla (vrt. Engle, Kane \& Tuholski, Miyaken \& Shahin 1999, mukaan). Viimeisten noin 30 vuoden aikana työmuistiteoria on saanut runsaasti huomiota. Ensiksi sen esittelivät vuonna 1974 Baddeley ja Hitch, ja vuoteen 1980 mennessä siitä oli tullut vallalla oleva lähestymistapa tarkkaavaisuus- ja muistitutkimuksissa (Miyake \& Shah 1999). Kuhnin (1963) mukaan paradigmat eivät nopeasti vaihdu ellei uudella paradigmalla ole entisïn verrattuna suurta selitysvoimaa. Työmuistimallia on modifioitu vain vähän (Baddeley 1986; 2000; 2001; 2003) ja modifiointi on perustunut empiirisesti validoituun tutkimukseen. Työmuistiteoria on vankka tarkkaavaisuus- ja muistiteoria ja sitä on laajasti testattu.

Just ja Carpenter $(1987$; 1992) lisäsivät kapasiteetin käsitteen työmuistiteoriaan. Heidän mukaansa työmuisti voidaan nähdä toimintaresurssien varantona, joka paitsi arvioi ja prosessoi (attend to), myös varastoi (memory) tietoa. Työmuisti on riippuvainen ihmisten erilaisesta kapasiteetista varastoida ja prosessoida informaatiota. Kapasiteetti ei laajene mutta tietoa voi oppia prosessoimaan tehokkaammin, jolloin on enemmän muistia käytössä. Yksilön kognitiivinen järjestelmä koostuu työmuistista, prosessitiedosta ja varastoidusta tiedosta (pitkäkestoinen muisti). Tieto varastoituu pitkäkestoiseen muistiin erillään työmuistista, mutta sen sisääntulo tapahtuu työmuistin kautta. Prosessitieto on ymmärrystä prosessin toiminnasta ja tämä ymmärrys, usein jäsentyneenä skeemoiksi, voi lisätä prosessoinnin tehokkuutta. Lisäksi prosessitieto ja pitkäkestoinen muisti ovat usein aiempien kokemuksiemme tulosta. Kokonaistyömuistia ei pidä sekoittaa prosessoimisen tehokkuuteen. Prosessoimisen tehokkuus on osa työmuistin kapasiteetin tarkkaavaisuuden suuntaamisosuutta, ja mitä vähemmän yksilö käyttää resursseja tarkkaavaisuuden suuntaamiseen, sitä enemmän jää resursseja muistiinpainamiseen. Työmuisti on dynaaminen systeemi, jota käytetään paitsi ärsykkeen siirtämisessä ja sitä seuraavassa ymmärtämisessä pitkäkestoisesta muistivarastosta ja -varastoon, myös luomaan uusia merkityksiä. Työmuisti liittyy yleiseen älykkyyteen, oppimiseen ja ymmärtämiseen. Ihmiset, joilla on suuri työmuistikapasiteetti, pystyvät ymmärtämään monimutkaista asiaa, muistamaan tarkemmin sivujuonia, jopa irrelevantteja pääjuoneen nähden, ja jopa yhdistelemään toisiinsa ajallisesti ja kontekstiltaan eroavia väitteitä ja ehdotuksia.

Työmuistikapasiteettia on testattu span(aikajänne)-tutkimuksin, ja ne joilla on pienempi kuuntelun aikajänne, käyttävät kapasiteetistaan enemmän prosessointiin ja ymmärtämiseen ja tällöin mieleen palauttamiseen jää vähemmän kapasiteettia. Henkilöillä, joilla on pidempi kuuntelun aikajänne, on isompi kuuntelukapasiteetti ja he voivat pitää monia tulkintoja aktiivisina väliaikaisessa varastossa pitempiä aikoja ja enemmän kuin lyhytjänteiset kuuntelijat. Tämä voi tehdä pitkäjänteisistä kuuntelijoista parempia keskustelijoita, koska 
he voivat valikoida responssivalikoimistaan sopivimmat responssit. Yksilön perustyömuistikapasiteetti on vakio, mutta funktionaalinen työmuistikapasiteetti voi lisääntyä tai vähentyä sen mukaan, miten yksilö prosessoi tietoa ja millaista tietoa hänellä on ennalta pitkäkestoisessa muistivarastossaan.

Yksi kielen kuvaajista on sen syntaksi, kielioppi, lauserakenteet ja kielen säännöt. Justin ja Carpenterin (1992) mukaan ihmisillä, joilla on pieni kieleen liittyvä työmuisti, saattaa puuttua kykyä ylläpitää (pitää aktiivisena ja kerätä lisäaktivaatiota) ei-syntaktista informaatiota syntaktisen tiedonkeruun aikana. Rajoitetun työmuistikapasiteetin omaavilla voi myös olla vaikeuksia käsitellä verbaalisista ja nonverbaalisista havainnoista syntyneitä merkityksiä. Luetun ymmärtämisen käsittein Just ja Carpenter esittävät, että kapasiteetti on motivaatiota parempi luetun ymmärtämisen ennustaja, mutta tätä väitettä he eivät ole testanneet.

Keskustelukuntelun kapasiteetti ja työmuistiteoria. Keskustelukuuntelun kapasiteetin mittaamisen perustana on työmuistiteoria. Mittaaminen pohjautuu kognitiivisen psykologian tutkimuksen perinteisiin kielen prosessointitehtäviin, joita on käytetty mittaamaan työmuistin kapasiteettia. Tällaisia ovat lukemisen (Reading span), puhumisen (Speaking span) ja kuuntelemisen (Listening span) aikajännetestit (Daneman \& Carpenter 1980; Daneman \& Green 1986). Lukemisen aikajännetestissä osallistuja lukee ääneen sarjan irrallisia lauseita pitäen mielessään jokaisen lauseen viimeisen sanan. Palautuskäskyn jälkeen hänen on toistettava jokaisen lauseen viimeinen sana. Lukemisen aikajännetestin keskiarvopisteet (asteikolla 1-5) ovat olleet 2.46 (Janusik 2004), 2.9 (Daneman \& Carpenter 1983) ja 3.63 (Waters \& Caplan 1996). Kuuntelemisen aikajännetesti on hyvin samantapainen kuin lukemisenkin, sillä erolla, että lauseet on äänitetty ja osallistuja kuuntelee lauseita ja yrittää pitää jokaisen lauseen viimeisen sanan aktiivisena mielessään. Keskiarvot kuuntelemisen testissä ovat olleet (asteikolla 1-5) 2.4 (Morris \& Sarll 2001), 2.89 (Janusik 2004) ja 2.95 (Daneman \& Carpenter 1980).

Viimeisin kielen prosessointia kuvaava instrumentti, jota on käytetty mittaamaan työmuistin kapasiteettia, on puhumisen aikajännetesti. Tässä tehtävässä osallistuja lukee ääneen 7-kirjaimisia sanoja ja pyrkii sitten tuottamaan ja sanomaan ääneen kicliopillisesti oikean lauseen joka sanasta. Tehtävä eroaa lukemisen ja kuuntelemisen aikajännetesteistä siinä, että se sisältää myös tuotoskomponentin, ei vain pelkkää toistokomponenttia. Lukemisen ja kuuntelemisen aikajännetesteissä osallistujan pitää toistaa vain esitetty ärsyke (viimeinen sana). Puhumisen aikajännetestissä osallistujan taas täytyy, paitsi muistaa alkuperäinen ärsyke, myös laatia jokaisesta alkuperäisestä ärsykesanasta jokin lause eli rakentaa ärsykkeelle merkitys omassa ajatusmaailmassaan. Pelkkä automaattinen toisto ei riitä. Kyseinen testi voidaan näistä perinteisistä työmuistitesteistä 
eniten tulkita viestinnäksi. Puhumisen aikajännetestin keskiarvot ovat olleet (asteikolla 1-5) 3.00 (Janusik 2004) ja 3.28 (Daneman \& Green 1986).

Lukemisen ja kuuntelemisen aikajännetestit ovat luonteeltaan lineaarisia, sillä osallistuja toimii vain informaation varastoijana. Puhumisen aikajännetesti lähestyy viestinnän vuorovaikutusmallia, mutta siinä osallistuja on vuorovaikutuksessa tietokoneen, ei ihmisen kanssa. Ärsykesanat luetaan tietokoneen ruudulta ja niistä tuotetut lauseet vain kerrotaan tutkijalle, joka listaa ne. Keskustelukuuntelun aikajännemittari on keskustelunomainen, mittaukset tehdään reaaliajassa ja se simuloi viestinnän transaktiomallia. Yhteenvetona voidaan todeta, että kaikki perinteiset kielen prosessointitehtävät ja -testit ovat dataperustaisia (data-driven; Bentley 1993) eli sanoja prosessoidaan ilman yhtenäistä semanttista kontekstia; lukemisen ja kuuntelemisen aikajännetestien lauseet ovat irrallisia pitkäkestoisen muistin vaikutusten eliminoimiseksi (Haarman, Davelaar, \& Usher 2003). Samoin puhumisen aikajännetestin sanat ovat irrallisia, joten osallistujan on tavallaan luotava sopiva konteksti joka sanalle erikseen. Keskustelukuuntelun aikajännemittarin tehtävät ovat puolestaan kontekstiperustaisia (context-driven; Bentley 1993), eli osallistuja valitsee satunnaistetusti keskustelunaiheen, josta syntyy jossain määrin yhtenäinen semanttinen kontcksti. Vaikka alaotsikot keskustelunaiheen sisällä vaihtuvat, kaikki kysymykset liittyvät kuitenkin samaan semanttiseen kontekstiin. Ne herättävät saman tai samanlaisen skeeman yksilön kognitiivisella alustalla, jolla hän jäsentää, tulkitsee, ymmärtää ja varastoi informaatiota (Fitch-Hauser 1990). Viime aikoina onkin todettu (Haarman, Davelaar, \& Usher 2003), että käsitteellisesti organisoidut mittarit tarjoavat tarkempaa tietoa työmuistikapasiteetista kuin perinteiset kielenprosessointia kuvaavat mittarit.

Keskustelukuuntelun aikajännemittari eroaa perinteisistä työmuistitesteistä kolmella tavalla:

1. Toisin kuin lukemisen ja kuuntelemisen aikajännetesteissä, keskustelukuuntelumittarin lauseet ja kysymykset liittyvät toisiinsa, kuten myös oikeassa keskustelussa usein tapahtuu.

2. Osallistujan tulee toistaa ajatuksia, ei tiettyjä sanoja. Näin tapahtuu, kun osallistuja toistaa kysymyksen omin sanoin ja vastaa siihen.

3. Keskustelukuuntelun aikajännetestissä tutkija toimii oikean vuorovaikutuksellisen keskustelukumppanin tavoin.

Keskustelukuuntelumittari välttää myös sen kritiikin, jota kuuntelemisen ja lukemisen aikajännetestit pelkkinä mieleenpalautus- ja toistotesteinä ovat saaneet osakseen (Steinbrecher \& Willmington 1997; Watson \& Barker 2000), sillä sïnä ei tarvitse toistaa sanatarkasti tiettyjä sanoja, vaan niitä voi esimerkiksi käyttää eri muodoissaan, kunhan vain osoittaa kuunnelleensa ne. Myöskään pitkäkestoisen muistin tietovaraston erot eivät ole ratkaisevia, koska osallistuja voi osoittaa muistamisensa esimerkiksi toistamalla alkuperäisen lauseen 
ajatuksen ja toteamalla sitten, ettei tiedä vastausta esitettyyn kysymykseen. Näin tapahtuu myös todellisissa keskusteluissa: kaikkea ei voi aina tietää, mutta on korrektia pitää kontaktia yllä ja kertoa keskustelukumppanille kuulleensa kysymyksen mutta ei tietävänsä vastausta.

Keskustelukuuntelun aikajännetestin (CLS) on todettu olevan validi mittari funktionaaliselle työmuistikapasiteetille keskustelussa silloin, kun keskustelukielenä on englanti (Janusik 2004). Validius perustuu siihen, että sillä on osoitettu olevan suoraan yhtenevyyksiä lukemisen, puhumisen ja kuuntelemisen aikajännetestien pisteisiin, jotka kaikki kolme testiä on osoitettu olevan työmuistin valideja mittareita (Daneman \& Merikle 1996). Mittarin validiuden testaaminen jollakin muulla kielellä kuin englanniksi on uusi haaste.

Suomen ja englannin kielen erot. Suomen kieli edustaa ei-indoeurooppalaista kieliryhmää, kun taas englanti edustaa indoeurooppalaista kieliryhmää ja kyseiset ryhmät eroavat toisistaan suuresti (Halsband, Krause, Sipilä, Teräs \& Laihinen 2002).

Kielitieteen näkökulmasta (Comrie 1989), suomen ja englannin kielet kuuluvat kahteen eri typologiseen ryhmään: suomen kieli on synteettinen ja englannin kieli analyyttinen. Synteettisessä kielessä prefiksit ja suffiksit ovat suoraan kiinni sanavartalossa ja sanoissa on monia taivutusmorfeemeja. Prefikseillä ja suffikseilla on itsenäisiä merkityksiä, mutta ne civät voi esiintyä ilman sanavartaloa. Kielen ollessa analyyttinen, ilmausten merkitykset syntyvät erillisten sanojen, kuten pre- ja postpositioiden välityksellä. Kyseinen typologinen ero tarkoittaa, että suomen kielen sanat harvoin esiintyvät perusmuodoissaan kielen arkikäytössä. Vaikka suomen kielen typologia on englannin kieltä kompleksisempi, suomen kielen oikeinkirjoitus on johdonmukaisempi ja yhtenäisempi kuin englannin kielen, sillä suomen kielen kirjain-äännevastaavuus on säännöllisempi ja symmetrisempi (Aro \& Wimmer 2003). Englannin kielen oikeinkirjoitusta on itse asiassa pidetty jopa yhtenä epäyhtenäisimmistä koko maailmassa.

Nämä kielitypologiset erot saattavat vaikuttaa myös esimerkiksi kielen lukunopeuteen. Lukunopeus voi toki selittyä myös koulutusjärjestelmän tai oppimismenetelmien eroilla (Linnakylä, Malin, Blomqvist, \& Sulkunen (2000). Englanninkielisissä maissa lapset aloittavat koulun käynnin yleensä n. 5-vuotiaina, kun taas suomalaiset lapset 7-vuotiaina. Kuitenkin suomalaiset lapset kolmannella luokallaan (n. 9 vuoden ikäisenä) lukevat huomattavasti yhdysvaltalaisia lapsia nopeammin (Aro \& Wimmer 2003), vaikka suomen kielen sanan keskipituus voi johdoskasaumineen ja etu- ja jälkiliitteineen olla paljonkin englanninkielistä sanaa pidempi. Suomenkielisen puhutun kielen sanan keskiarvopituus on noin 4,6 äännettä sanassa (Pajunen \& Palomäki 1984). Sen sijaan helpohkossa kirjoitetussa (sanomalehtien pikku uutisten) tekstissä sanojen keskiarvopituus on 7,5 kirjainta sanassa. Puhutun ja kirjoitetun suomen 
kielen sanapituuden vaihteluväli on 1-20 äännettä/ kirjainta sanassa (Pajunen \& Palomäki 1984). Koska keskiverto sanapituus 7,5 kirjainta on laskettu helpohkosta tekstistä, todellinen keskiarvosanapituus saattaa olla jopa enemmän kaikkine taivutusmuotoineen ja johdoksineen.

Suomalaisten kuva itsestään, samoin kuin muiden kulttuurien kuva suomalaisista viestijöinä, on varsin yhtenevä: suomalaisia pidetään ujoina, vetäytyvinä ja vain vähän ulospäin suuntautuneina (Laine-Sveiby 1987; Lehtonen 1993; Sallinen-Kuparinen 1986). Puhujan roolia kunnioitetaan, puhujaa ei juuri keskeytetä eikä pitkää hiljaisuutta välttämättä koeta epämukavaksi (Lehtonen \& Sajavaara 1985). Kuuntelemisen taitoja arvostetaan (vrt. Mikkola 2000; Tiuraniemi 2004; Välikoski 2002; 2004) ja esimerkiksi opiskelijat erottavat kuuntelemisen taidot puhumisen taidoista arvioiden itsensä usein hyväksi kuuntelijaksi vaikkakaan eivät pidä itseään hyvinä puhujina; tämä on kuitenkin spekulaatiota eikä empiirisesti todettua.

Suomalaisen puheviestintätutkimuksen näkökulmasta kuuntelukapasiteetti oli aiheena kiinnostava, koska kuuntelemisen tutkimus on Suomessa vielä melko vähäistä. Kuitenkin kyky kuunnella keskustelukumppanin ajatuksia hyvin on keskustelussa yhtä tärkeää kuin kyky ilmaista omia ajatuksiaan.

Keskustelukunntelemisen aikajännemittari (Conversational Listening Span, CLS). Keskustelukuuntelemisen aikajännetesti (Conversational Listening Span, CLS) mittaa kokeellisesti henkilöiden keskustelukuuntelemisen kapasiteettia, joka määritellään niiden kognitiivisten merkityksien määräksi, joita henkilö kykenee pitämään aktiivisena muistissaan ja joihin hän pystyy vastaamaan keskustelun kuluessa (Janusik 2004). Keskustelukuuntelun kapasiteetti liittyy yksilön kykyyn olla keskustelussa mukana, osallistua aktiivisesti, muistaa aiemmin sanotut asiat ja osata tuoda omat ajatukset juohevasti osaksi keskustelua myös silloin kun puheenvuoroa joutuu odottamaan.

Keskustelukuuntelun aikajännemittari perustuu työmuistiteoriaan (Baddeley \& Hitch 1974; Baddeley 1986; 2001) ja myös relationaaliseen viestinnän näkökulmaan, jossa ajatellaan osallistujien reagoivan toisiinsa samanaikaisesti vuorotellen puhujan ja kuulijan rooleissa (Brownell 1999; Rhodes 1993). Keskustelukuuntelun aikajännemittari eroaa muista kuuntelemisen mittareista, kuten itsensä havainnoinnista kuuntelijana (Barker \& Watson 2000; Roberts \& Vinson 1998; Wheeless 1975), toisen henkilön havainnoinnista kuuntelijana (Emmert, Emmert \& Brandt 1993; Rubin 1982) ja kuullun ymmärtämistä mittaavista välineistä (Steinbrecher \& Willmington 1997; Watson \& Barker 2000) kolmella tavalla:

1. Se mittaa vuorovaikutusta reaaliajassa ja eroaa aiemmasta tutkimuksesta siinä, että se tarkastelee kuuntelemista relationaalisesta näkökulmasta aiemman lineaarisen näkökulman sijasta. Kuuntelu viestintätekona ei tapahdu 
tyhjiössä, lähettäjä on myös vastaanottaja ja vastaanottaja on lähettäjä samanaikaisesti ja vuorotellen. Termit puhuja ja kuuntelija vain tekevät viestintäprosessin helpommaksi selittää (Berlo 1960).

2. Se ei ole sidottu pitkäkestoisen muistin käsitteeseen eikä ole siitä riippuvainen, mitä on aiemmissa kuunteluinstrumenteissa kritisoitu (Bostrom 1996; Fitch-Hauser \& Hughes 1988; Janusik 2003; Thomas \& Levine 1994; Roberts 1988).

3. Se liittyy työmuistikapasiteetin konstruktioon (Just \& Carpenter 1992), joka on kognitiivisessa psykologiassa empiirisesti validoitu konstruktio ja jonka perusteella voidaan testata erilaisia kuunteluteorioita.

Keskustelukuuntelun kapasiteetti mittaa kuuntelua keskustelun kuluessa. Tarkoituksena on rakentaa kuuntelemisesta malli, joka yhdistää kognitiivista psykologiaa, neurologiaa ja viestintätutkimusta.

Tutkimushypoteesit. Perinteisistä kielen prosessointia kuvaavista aikajännetesteistä keskustelukuuntelun aikajännetesti (CLS) muistuttaa eniten puhumisen aikajännetestiä (Speaking span) tuotoskomponenttinsa ansiosta. Osallistujan täytyy tuottaa ajatus, joka ei ole osa ärsykettä. Yksi askel kohti kriteereillä perusteltavaa validiutta on osoittaa testin merkittävä yhtenevyys tai eriävyys toiseen instrumenttiin, jonka ajatellaan mittaavan samoja tai vastakkaisia komponentteja. Yhdysvaltalaisella keskustelukuuntelun aikajännetestillä on osoitettu kriteeriperusteinen validius aiempaan tutkimukseen (Janusik 2004). Siispä ensimmäinen hypoteesi kuuluu:

$H_{j}:$ Sekä ybdysvaltalaisen että suomalaisen osallistujan keskustelukwuntelun aikajännetestipisteet korreloivat pubumisen aikajännetestin pisteiden kanssa.

Keskustelukuuntelun kapasiteettitestiin luotiin erilaisia ja oletettavasti myös eri tavoin osallistujia kiinnostavia keskusteluaiheita, jotta voitiin tutkia kiinnostuneisuuden vaikutusta tuloksiin. Intuitiivisesti voi olettaa, että jostakin aiheesta enemmän kiinnostunut voi saada korkeammat pisteet kuin se, jota kyseinen aihe ei lainkaan kiinnosta. Kuitenkin, Justin ja Carpenterin (1992) ja Janusikin (2004) mukaan motivaatiolla ei ole yhteyttä kapasiteettiin. Keskustelukuuntelun kapasiteettitesti on suunniteltu mittaamaan kapasiteettia, ei kiinnostuneisuutta. Kyseinen väite haluttiin testata myös suomalaisella aineistolla. Näin kehittyi toinen hypoteesi:

$\mathrm{H}_{2}$ : Keskustelun aihealueestaan kiinnostuneempi osallistuja saa korkeammat keskustelukuuntelun kapasiteettipisteet kuin aibealueestaan väbemmän kiinnostunut osallistuja sekä ybdysvaltalaisessa että suomalaisessa kulttuurissa. 
Kyse oli ensimmäisestä muulla kuin englannin kielellä tehdystä keskustelukuuntelun kapasiteettitutkimuksesta, joten molemmissa testeissä käytetyt mittarit käännettiin suomeksi englanninkielisestä versiosta. Englanninkielinen puhumisen aikajännetesti (Speaking span) sisälsi 7-kirjaimisia sanoja, jota pidetään englannin kielen keskimääräisenä sanapituutena. Suomen kieli on englantia kompleksisempi, sen keskiarvosanapituus voi olla pidempi, mutta tässä tutkimuksessa käytettiin englanninkielen mallin mukaisia 7-kirjaimisia suomen kielen sanoja. Sanat tosin saattavat olla suomenkielisille mahdollisesti hieman lyhyitä. Suomen kieli on oikeinkirjoitukseltaan johdonmukaisempaa kuin englanninkieli, ja suomalaiset lapset lukevat yhdysvaltalaisia nopeammin. Siksi asetettiin kolmanneksi hypoteesiksi:

\section{$H_{3}$ : Suomalainen osallistuja saa korkeammat pisteet pubumisen aikajännetestissä kuin ybdysvaltalainen osallistuja.}

Keskustelukuuntelun aikajännetesti mittaa kognitiivista kuuntelukapasiteettia ja kykyä reagoida ideoihin kapasiteettinsa puitteissa. Kognitioon kuuluvien ajatusten pituutta ei voi mitata, siksi ei ole mitään syytä olettaa ajatuksen olevan lyhyempi tai pidempi englannin tai suomen kielessä. Vaikka suomalaiset lukevat nopeammin, keskustelukuuntelun kapasiteettitesti toteutetaan kuuntelemalla, ja tutkija kontrolloi puheen vauhtia. Joka tapauksessa sekä sanojen lukeminen että kuunteleminen vaativat kielen prosessointia Just \& Carpenter 1987), ja koska suomalaiset opiskelijat prosessoivat visuaalisia sanaärsykkeitä yhdysvaltalaisia tehokkaammin, he saattavat prosessoida myös kuuloärsykkeitä näitä nopeammin. Siispä neljänneksi hypoteesiksi asetettiin:

$\mathrm{H}_{4}$ : Suomalainen osallistuja saa korkeammat pisteet keskustelukuuntelun aikajännetestissä kuin ybdysvaltalainen osallistuja.

Vaikka keskiarvot voivat olla huomattavasti erilaisia näiden kahden ryhmän välillä, voi silti olla mahdollista, että näiden ryhmien tulosten suhteet korreloivat keskenään. 'Tutkimukset ovat osoittaneet, että keskustelukuuntelun ja puhumisen aikajännetestien pisteet (Daneman \& Green 1986; Janusik 2004) muodostavat normaalijakauman yhdysvaltalaisessa (Janusik 2004) ja kanadalaisessa (Daneman \& Green 1986) populaatiossa. Ei siis ole Millerin (1956; 1994) aiempien tutkimusten mukaan tavatonta, että ihminen voi pitää muistissaan aktiivisena keskimäärin seitsemän plus/miinus kaksi asiaa. Niinpä saatiin viides hypoteesi: $H_{5}:$ Korrelaatio keskustelukuuntelun ja pubumisen aikajännetestien välillä on ybtenevä
molemmissa kulttuureissa. 


\section{TUtKImUSmenetelmät JA OSALlistujat}

Tutkimusaineisto koostui kahdesta opiskelijaryhmästä: toinen ryhmä oli yhdysvaltalaisia ja toinen suomalaisia opiskelijoita. Yhdysvaltalaisia opiskelijoita oli 283 suuresta itäpuolen yliopistosta. Iältään he olivat keskimäärin 20.38-vuotiaita $(S D=3.55)$ ja naisia heistä oli 176 ja miehiä 107. Opiskelijat saivat ylimääräisen opintopisteen osallistumisestaan tutkimukseen ja he olivat suorittamassa erilaisia viestinnän kursseja (basic communication, interpersonal communication, communication research methods ja listening). Aineiston keräsi 17 opiskelijaa ja projektin vetäjänä toimi yhdysvaltalainen tutkija.

Suomalainen ryhmä oli 45 opiskelijaa Tampereen yliopistosta. Opiskelijoiden keskiarvoikä oli $23.98(\mathrm{SD}=5.09)$ ja naisia heistä oli 35 ja miehiä 10. Opiskelijat rekrytoitiin vapaaehtoisina erilaisilta puheopin kursseilta (puheviestinnän perusteet, pienryhmäviestintä ja neuvottelutaito). Aineiston keräsi kuusi puheopin aineopintojen opiskelijaa osana puheviestinnän tutkimuksen opintojaan, ja he olivat yhdessä kouluttautuneet hoitamaan tutkimusprotokollan yhtenäisellä tavalla. Tutkimuksen toteutustapa oli heillä keskenään yhtenevä ja yhtenäinen myös verrattuna yhdysvaltalaiscen aineistonkeruuseen. Projektin vetäjinä toimivat tämän artikkelin suomalaiset tekijät.

Koejärjestelyt olivat samanlaiset sekä yhdysvaltalaisessa (Janusik 2004) että suomalaisessa tutkimuksessa. Testin alussa allekirjoitettiin osallistujan kanssa tutkimus- ja videokuvauslupa (yhdysvaltalaisen käytännön mukaisesti). Sen jälkeen osallistuja laittoi omaan kiinnostavuusjärjestykseensä viisi keskustelunaihealuetta. Aihealueita olivat musiikki, urheilu, yliopistoelämä, televisio sekä historia ja politiikka. Sitten osallistuja teki puhumisen aikajännetestin. Osallistuja näki puhumisen aikajännetestin ohjeet tictokoneen ruudussa ja tutkija luki ne hänelle vielä ääneen. Osallistuja harjoitteli ensin testiä ja sai harjoituksesta tutkijalta palautteen. Kun osallistuja oli suorittanut puhumisen aikajännetestin, hän arpoi itselleen keskustelunaiheen (nopan pisteet 1-3 = häntä vähiten kiinnostava aihe ja 4-6 = kiinnostavin aihe). Tämän järjestelyn tarkoituksena oli selvittää osallistujan kiinnostuneisuutta, jotta toisen hypoteesin väite oli mahdollista testata.

Osallistujalle kerrottiin, että häneltä tullaan kysymään asioita aluksi lähtien kahden lauseen sarjoista ja lopuksi päätyen viiden lauseen sarjoihin. Hänen tuli toistaa kunkin sarjan lauseet omin sanoin ja vastata niihin sen mukaan, mitä asiasta tiesi tai mitä tunteita se herätti. Jos vastausta ei tiennyt, osallistujan tuli kuitenkin toistaa kysymys (osoittaakseen muistavansa sen) ja vastata siihen "en tiedä". Osallistuja ei saanut toistaa kaikkia kysymyksiä kerralla, vaan hänen tuli toistaa yksi kysymys, vastata siihen, toistaa seuraava ja vastata siihen. Näin siksi, että haluttiin tutkia työmuistia eikä pelkästään lyhytkestoista muistia. Lyhytkestoisen muistin kesto on 15 sekuntia (Bostrom 1990). Jos osallistujalla kestää pitempään kuin 15 sekuntia toistaa kysymys, vastata siihen, toistaa seuraava kysymys jne., hän pystyy pitämään työmuistissaan aktiivisina asioita pitempäänkin 
kuin vain tuon 15 sekuntia. Osallistuja sai vastata kysymyksiin haluamassaan järjestyksessä. Aineiston kerääjä varmisti osallistujan ymmärtäneen ohjeet pyytämällä häntä toistamaan ne. Ohjeet selitettiin niin kauan kunnes osallistuja osoitti ymmärtäneensä ne. Kuten puhumisen aikajännetestissä, myös tässä oli ensin harjoituskierros, josta osallistuja sai rakentavan palautteen. Koska aineiston kerääjiä oli useita, tutkijaefektin kontrolloimiseksi ohjeistukseen kuului myös lista verbaalisia ja nonverbaalisia palautteita tai muuta käyttäytymistä, jotta toiminta oli samanlaista kaikissa aihealueissa. Jotkut ohjeista olivat hyvin tarkkoja, kuten "nojautuu lähemmäs pöytää ja laittaa kyynärpäät pöydälle" ja toiset olivat yleisempiä, kuten "antaa myönteistä palautetta osallistujan jonkin vastauksen kohdalla tässä lausesarjassa". Aineiston kerääjiä ohjeistettiin mukauttamaan nonverbaaliset palautteensa omaan viestintätyyliinsä sopiviksi sekä amerikkalaisessa että suomalaisessa kulttuurissa.

Pubumisen aikajännemittari (Speaking span). Yhdysvaltalaiset osallistujat käyttivät keskustelukuuntelun kapasiteetin mittarin validoinnissa oheistestinä kognitiivisen psykologian tutkimuksen traditionaalista puhumisen aikajänne -mittaria (Speaking span). Kyseinen testi perustui Danemanin ja Greenin (1986) formaattiin, jossa 7-kirjaimiset sanat näytettiin yksi kerrallaan mutta testin edetessä pitenevinä 2-7 sanan sarjoina osallistujalle. Osallistujan tuli lukea sanat ääneen. Kunkin sanasarjan jälkeen mieleenpalautuskehotuksen saatuaan osallistuja toisti sarjan sanat ja sanoi jokaisesta kieliopillisesti oikean lauseen. Kyseistä englanninkielistä testiä ei käännetty suoraan suomen kielelle, sillä englanninkieliset 7-kirjaimiset sanat olisivat usein olleet pidempiä suomenkielisinä käännöksinä. Sanat pyrittiin suomenkielisessä versiossa kuitenkin korvaamaan saman aihepiirin sanoilla kuin englanninkielisessä oli. Kirjainten lukumäärästä pidettiin tässä vaiheessa kiinni myös suomenkielisessä testissä, koska oletettiin erikielisten testien yhteismitallisuuden niin vaativan.

Keskustelukuuntelemisen aikajännemittari. Sekä yhdysvaltalaiset että suomalaiset osallistujat tekivät keskustelukuuntelun kapasiteettitestin Janusikin (2004) esittämän työjärjestyksen mukaisesti. Tehtävässä oli viisi aihealuetta: urheilu, yliopistoelämä, televisio, musiikki sekä historia ja politiikka. Osallistujat arpoivat näistä satunnaisesti keskustelunsa aihealueen. Suomalainen versio oli lähes identtinen, tosin jotkut kysymykset muovailtiin paremmin suomalaiseen kulttuuriin sopivaksi, kuten esimerkiksi amerikkalainen yliopistourheilu mestaruussarjoineen vaihdettiin suomalaiseen kuntoilupainotteisempaan yliopistoliikuntaan tai yhdysvaltalaiset historian merkkihenkilöt ja -tapahtumat korvattiin suomalaisilla vastaavilla. Kysymysten keskeinen luonne säilytettiin samana molemmissa kieliversioissa eli avoin kysymys korvattiin avoimella, mielipide- tai faktakysymys vastaavalla suomenkielisellä. 
Tutkijat esittivät kysymykset mahdollisimman keskustelunomaisesti, vaikka heillä olikin mahdollisuus käyttää kysymyskortteja muistin tukena. Kysymyssarjojen järjestys oli sama kuin perinteisessä Danemanin ja Carpenterin (1980) sekä Danemanin ja Greenin (1986) kielen prosessointitestissä. Kysymyksiä oli kolme kahden lauseen, kolme kolmen lauseen, kolme neljän lauseen ja kolme viiden lauseen sarjaa. Osallistujan tuli toistaa kukin kysymys ennen siihen vastaamista. Jos vastausta ei tiennyt, tuli silti toistaa kysymys ja vastata siihen "en tiedä", mikä tulkittiin oikeaksi vastaukseksi. Kyseinen muoto jäljitteli todellista keskustelua, jossa keskustelijoiden ei odoteta tietävän aina kaikkea.

Testin säännöt ja pisteytys. Testin tiukat säännöt vaativat osallistujia toistamaan sanat siinä järjestyksessä kuin ne esitettiin, mutta lievät säännöt sallivat toiston missä tahansa järjestyksessä. Tässä tutkimuksessa sovellettiin pisteiden laskun lieviä sääntöjä (Daneman 1991) sekä puhumisen aikajänne- että keskustelukuuntelun kapasiteettitestissä, sillä todellisissakaan keskustelussa ei yleensä vaadita vastauksilta tiettyä järjestystä. Testin pisteet laskettiin Whitneyn, Ritchien ja Clarkin (1991) pisteytystavan mukaisesti: jos osallistuja onnistui kahdessa kolmesta yhteen lausesarjaan kuuluvasta kysymyksestä, hän siirtyi seuraavaan sarjaan. Tätä jatkettiin niin kauan kunnes osallistuja sai vain yhden tai ei ollenkaan oikein sarjassa. Osallistujan lopullinen pistemäärä oli se taso, jossa kaksi kolmesta lausesarjasta oli oikein. Jos osallistuja sai seuraavalta tasolta yhden kokonaisen lausesarjan kolmesta oikein, tämä toi hänelle 0.5 lisäpistettä, mutta ei pääsyä yrittämään seuraavaa tasoa. Jos osallistuja sai esimerkiksi kaksi kolmesta oikein kakkostasolla (maksimitaso oli 5) mutta vain yhden kolmesta oikein kolmannella tasolla, hänen pisteensä olivat 2.5 .

\section{Tulokset}

Keskustelukuuntelun aikajännetestien pisteiden keskiarvojen erot eivät poik-

\begin{tabular}{|l|l|l|l|l|}
\hline Mittari & keskiarvo & keskihajonta & min. & max. \\
Ss, amer. & 3.10 & .627 & 1.00 & 5.00 \\
\hline Ss, suom. & 3.46 & .940 & 1.00 & 7.00 \\
\hline CLS, amer. & 3.05 & 0.862 & 1.00 & 5.00 \\
\hline CLS, suom. & 3.02 & 0.869 & 1.00 & 5.00 \\
\hline
\end{tabular}

Taulukko 1. Pubeen (Ss) ja keskustelukuuntelun (CLS) aikajännetestien pisteiden keskiarvot. 
kea toisistaan amerikkalaisessa ja suomalaisessa aineistossa. Puheen aikajännetestissä suomalaisten pistekeskiarvo, hajonta ja maksimipistemäärä olivat korkeampia kuin amerikkalaisten. Nämä tiedot ovat taulukossa 1.

Hypoteesissa 1 oletettiin keskustelukuuntelun ja puhumisen aikajännetestien pisteiden välille yhteys. Näin olikin yhdysvaltalaisessa aineistossa, jossa näiden kahden vertailtavan testin pisteet korreloivat keskenään merkitsevästi $(\mathrm{r}=.16, \mathrm{p}$ $<.01$ ), korrelaatio on kuitenkin heikko. Suomalaisten osallistujien kohdalla korrelaatiota ei ollut $(r=.08, n s)$. Hypoteesi 1 , siis osittain toteutui (taulukko 2).

\begin{tabular}{|l|l|l|}
\hline Mittari & Ss & Cls \\
Ss, amer. & 1.00 & \\
\hline CLS, amer. & $.16^{*}$ & 1.00 \\
\hline Ss, suom. & 1.00 & \\
\hline CLS, suom. & .08 & 1.00 \\
\hline
\end{tabular}

\section{Taulukkeo 2. Pubeen (Ss) ja keskustelukuuntelun} (CIS) aikajännemittanien korrelaatiot.

Hypoteesissa 2 oletettiin, että jos testikeskustelun aihealue oli osallistujan kannalta hyvin kiinnostava, olisivat osallistujan saamat keskustelukuuntelun aikajännetestin pisteet korkeammat kuin jos aihe ei osallistujaa kiinnostaisi. Riippumaton ryhmien välinen t-testi ei osoittanut eroa testipisteissä yhdysvaltalaisten osallistujien kohdalla silloin, jos mielenkiinto aiheeseen oli suurta ( $M$ $=3.05, \mathrm{SD}=.79)$ tai pientä $(\mathrm{M}=3.04, \mathrm{SD}=.94) ; \mathrm{F}(4.68,279, \mathrm{p}=.03), \mathrm{t}=$ $-.152, \mathrm{p}>.05$, ns. Myös suomalaisten osallistujien kohdalla tilanne oli sama, eikä kïnnostuksella näyttänyt olevan merkitystä testipisteisiin (suuri kiinnostus $\mathrm{M}=2.98, \mathrm{SD}=.83$ versus pieni kiinnostus $\mathrm{M}=3.05, \mathrm{SD}=.925 ; \mathrm{F}(.095$, $43, \mathrm{p}=.76), \mathrm{t}=.256, \mathrm{p}>.05, \mathrm{~ns}$. Kummassakaan aineistossa keskustelun aiheen kiinnostavuudella tai ei-kiinnostavuudella ei ollut yhteyttä saatuihin pisteisiin eli hypoteesi 2 ei saanut tukea.

Tieto suomalaisten lasten paremmasta lukunopeudesta yhdysvaltalaisiin lapsiin verrattuna oli kolmannen hypoteesin perustana. Kolmannessa hypoteesissa oletettiin, että suomalaiset osallistujat saisivat puhumisen aikajännetestissä (Speaking span) yhdysvaltalaisia osallistujia parempia pisteitä. Näin tapahtui; 
suomalaiset osallistujat saivat huomattavasti korkeammat pisteet $(M=3.46$, $\mathrm{SD}=.94)$ kyseisessä testissä kuin yhdysvaltalaiset $(\mathrm{M}=3.10 \mathrm{SD}=.63) . \mathrm{F}(1.39$, $325, \mathrm{p}=.24), \mathrm{t}=3.31, \mathrm{p}<.001$ eli hypoteesi 3 sai tukea.

Hypoteesissa neljä oletettiin, että suomalaiset osallistujat saisivat korkeampia pisteitä keskustelukuuntelun aikajännetestissä kuin yhdysvaltalaiset osallistujat. Päinvastoin kuin hypoteesissa oletettiin, suomalaiset osallistujat eivät saaneet merkitsevästi korkeampia $(\mathrm{M}=3.01, \mathrm{SD}=.87)$ pisteitä kuin yhdysvaltalaiset $(\mathrm{M}=3.05 \mathrm{SD}=.86) ; \mathrm{F}(.193,324, \mathrm{p}=.66), \mathrm{t}=-.254, \mathrm{p}>.05$ ns. Hypoteesi neljä ei saanut tukea.

Viimeisessä hypoteesissa viisi oletettiin, että puhumisen ja keskustelukuuntelun aikajännetestien pisteet olisivat yhtenevät, korreloisivat keskenään molemmissa aineistoissa. Suomalaisten ja amerikkalaisten keskustelukuuntelun aikajännetestin pisteiden välillä oli erittäin vahva korrelaatio, mutta puhumisen aika¡ännetestin pisteiden välillä yhtenevyyttä ei ollut. Hypoteesi viisi piti osittain paikkansa, kuten taulukosta 3 havaitaan.

\begin{tabular}{|l|l|l|l|l|} 
Mittati & $\begin{array}{l}\text { Amer. } \\
\text { Ss }\end{array}$ & $\begin{array}{l}\text { Amer. } \\
\text { Cls }\end{array}$ & $\begin{array}{l}\text { Suom. } \\
\text { Ss }\end{array}$ & $\begin{array}{l}\text { Suom. } \\
\text { CLS }\end{array}$ \\
\hline Ss, amer. & 1.00 & & & \\
\hline CLS, amer. & $.163^{*}$ & 1.00 & & \\
\hline Ss, suom. & -.246 & .079 & 1.00 & \\
\hline CLS, suom. & -.261 & $.816^{*}$ & $.073 \quad * 01$ (kaksisuuntainen)
\end{tabular}

Taulukko 3. Pubeen (Ss) ja keskustelukuuntelun (CLS) aikajännetestien pisteiden korrelaatiot amerikkalaisessa ja suomalaisessa aineistossa.

\section{UOHTOPÄÄTÖKSET JA POHDINTA}

Tutkimuksella oli kaksi päätavoitetta. Toisaalta tutkittiin, onko keskustelukuuntelun aikajännetesti (CLS) myös suomenkielisenä versiona validi testi mittaamaan yksilön funktionaalista keskustelukuuntelemisen kapasiteettia jollaiseksi se on jo yhdysvaltalaisessa tutkimuksessa osoitettu (Janusik 2004). Tämä tavoite testattiin ensimmäisellä ja viidennellä hypoteesilla. Toisena tavoitteena oli tutkia yhdysvaltalaisten ja suomalaisten osallistujien pisteiden suhdetta. Tämä tavoite testattiin kolmannella ja neljännellä hypoteesilla. Toinen hypoteesi testasi kiinnostuksen merkitystä keskustelukuuntelun mittarilla. 
Kysymykseen siitä, onko keskustelukuuntelun aikajännetesti toimiva mittaamaan funktionaalista keskustelukuuntelemisen kapasiteettia, tämä tutkimus vastaa lähinnä suuntaa antavasti. Yhdysvaltalaisessa aineistossa Conversational Listening Span (CLS) todensi sisällöllisen, kriteereihin suhteutetun ja käsitteen validiteetin. (Janusik 2004.) Yksi käsitteellisen validitectin kriteereistä on, että tutkittava instrumentti korreloi suoraan ja selvästi sellaisen instrumentin kanssa, jonka on jo osoitettu mittaavan samaa tai samanlaista asiaa. Puhumisen aikajännetestiä on käytetty mittaamaan työmuistikapasiteettia ja sen on näytetty validisti mittaavan sitä. Hypoteesien yksi ja viisi oli tarkoitus testata, ovatko puhumisen ja keskustelukuuntelun aikajännetestien tuloksien suhteet yhtenevät erikielisissä aineistoissa. Tuloksena oli, että yhdysvaltalaisessa aineistossa näiden kahden testin pisteillä oli tilastollisesti merkitsevä vastaavuussuhde, mutta suomalaisessa aineistossa ei. Syynä saattaa olla suomalaisen puhumisen aikajännetestin rakenne.

Kuten aiemmin todettiin, suomen ja englannin kielet eroavat toisistaan kielitieteen näkökulmasta typologiansa, ortografiansa ja keskiarvosanapituutensa perusteella. Tässä tutkimuksessa keskiarvosanapituudet pidettiin kuitenkin samoina testin mahdollisimman suuren yhdenmukaisuuden vuoksi, vaikka tiedetäänkin suomalaisten lasten lukevan yhdysvaltalaisia lapsia nopeammin. Ei siis liene yllätys, että suomalaiset osallistujat saivat huomattavasti korkeampia pisteitä puhumisen aikajännetestissä kuin yhdysvaltalaiset osallistujat. Tämä voi selittyä kapasiteettiteorialla, jonka mukaan suomalaiset osallistujat osaavat prosessoida visuaalista ärsykettä yhdysvaltalaisia osallistujia tehokkaammin ja jättää näin enemmän kuuntelukapasiteettia muistïn varastoimista varten. Vaikka puhumisen aikajännetesti on verbaalinen testi, on siinä käytetty ärsyke esitetty visuaalisesti. Jatkotutkimuksessa voisikin selvittää, tulisivatko pisteet erilaisiksi, jos ärsyke esitettäisiin pelkästään auditïvisesti, kuten keskustelukuuntelun kapasiteettitestissä.

Toinen kiinnostava jatkotutkimusaihe olisi selvittää, olisiko suomalaisessa aineistossa selvä yhteys keskustelukuuntelun ja puhumisen aikajännetestien pisteiden välillä, jos käytettäisiin pitempiä kuin 7-kirjaimisia sanoja, ts. keskiarvosanapituus olisi suomen kieleen sopivampi. Suomalaislapset osaavat prosessoida yhdysvaltalaisia nopeammin, joten 7-kirjaimiset sanat ovat suhteellisen lyhyitä suomalaista standardia ja erityisesti aikuisväestöä ajatellen. Kyseinen sanapituus ei ehkä ollut aikuistestïn paras mahdollinen. Tosin tilastollisen merkitsevyyden puute voi epäsuorasti tukea Aron ja Wimmerin (2003) tuloksia suomalaislasten kielenprosessoinnin tehokkuudesta. Janusik (2004) teki samanlaisen havainnon ikäsopivuutta koskien tutkimuksessaan, jossa todettiin lukemisen aikajännetestin (Reading span) keskiarvopisteiden huomattavasti eroavan aiemmin esitetyistä tuloksista (Daneman \& Carpenter 1980; 1983; Daneman \& Green 1986); Janusik käytti testilauseiden konstruoinnissa Flesch- 
Kincaidin luettavuustasomittausta, jolla mitattuna Danemanin aiemman testin lauseet olisivat "helpompia". Yksi mahdollinen tulkinta on, että helpompi, ei ikään sopiva, ärsyke kuluttaa vähemmän prosessointikapasiteettia ja jättää siten enemmän varastointikapasiteettia. Mikäli jatkossa sanapituus on osallistujien ikään ja kulttuuriin sopivampi, saattaa myös suomalaisen aineiston puhumisen ja keskustelukuuntelun aikajännetestien pisteiden välillä löytyä vastaavuutta.

Yhdysvaltalaisen ja suomalaisen aineiston keskustelukuuntelun kapasiteettimittarin pisteiden välillä oli vahva korrelaatio. Molempien aineistojen pisteiden keskiarvot olivat hyvin samanlaiset. Yhdysvaltalainen aineisto oli määrältään yli viisinkertainen suomalaiseen nähden, joten suomalaista aineistoa on jatkotutkimuksissa kerättävä lisää, jotta voidaan aukottomasti todeta mittarin yhtenevä validius yhdysvaltalaisessa ja suomalaisessa aineistossa.

Suomalaisten lasten hyvä lukunopeus ja kolmannen hypoteesin toteutuminen (suomalaisten osallistujien korkeampi keskiarvo puhumisen aikajännetestissä), antaisi olettaa, että suomalaiset osallistujat saisivat korkeampia pisteitä myös keskustelukuuntelun kapasiteettitestissä. Näin ei kuitenkaan tapahtunut. Tämä vahvistaa ajatusta, että työmuistikapasiteetti muodostaa normaalijakauman isossa populaatiossa, kuten on osoitettu yhdysvaltalaisessa (Janusik 2004) ja kanadalaisissa (Daneman \& Carpenter 1980; 1983; Daneman \& Green 1986) tutkimuksissa. Vaikka keskiarvokapasiteetti näyttää olevan vähemmän kuin Millerin (1956; 1994) esittämä seitsemän plus tai mïnus kaksi -teoria, se on silti johdonmukainen. Yksi mahdollinen selitys on, että keskustelukuuntelun kapasiteettitesti on parempi mittaamaan työmuistikapasiteettia kuin traditionaaliset työmuistitestit (kuten Speaking span), koska se on kontekstiperustainen toisin kuin perinteiset työmuistitestit. Yhtenevät pisteet suomen- ja englanninkielisestä keskustelukuuntelun kapasiteettitestistä saattavat tukea Haarmanin ym. (2003) havaintoa, että konseptuaaliset mittarit ennustavat hyvin työmuistikapasiteettia, erityisesti silloin kun muuttuja muodostaa normaalijakauman populaatiossa. Jatkotutkimus voisi tuoda jotain uutta silloin, jos perinteisiin työmuistitesteihin luotaisiinkin toisiinsa liittyviä lauseita selvittämään kontekstin ja kanavan vaikutusta tuloksiin. Jatkossa voisi myös tutkia auditiivisen ja visuaalisen kanavan sekä data- ja kontekstiperustaisen testin eroja. Tällaiset tutkimukset tuovat esïn funktionaalisen työmuistikapasiteetin eri dimensioita, ja sitä kautta auttavat kuuntelemisen tutkijoita ymmärtämään niitä prosesseja, jotka liittyvät kuuntelemisen eri tyyppeihin.

Tämä tutkimus vahvistaa tutkimustulosta, että kiinnostus eri aihealueisiin ei vaikuta työmuistikapasiteettiin (Janusik 2004), mikä on tärkeää kuuntelukonteksteissa, joissa ei edellytetä etukäteistietoa tai sitoutumista aiheeseen. Tämän tutkimuksen tulosten perusteella sen sijaan ei tiedetä, miten nuo kaksi muuttujaa vaikuttavat kuullun ymmärtämiseen; sitä on syytä tutkia jatkossa. 
Keskustelukuuntelun aikajännetesti näyttää siis lupaavalta mittaamaan validisti funktionaalista keskustelukuuntelemisen kapasiteettia myös suomalaisessa kulttuurissa. Jatkotutkimuksissa voidaan käyttää nykyistä suomenkielistä keskustelukuuntelun kapasiteettimittaria mutta puhumisen aikajännetestiä on syytä kehittää edelleen osallistujien ikään ja suomalaiseen kulttuuriin sopivammaksi. Jatkotutkimuksissa voidaan käyttää lisämuuttujina myös kontekstillisuutta ja kontekstittomuutta testin rakentamisessa. Mittarin toimivuus eri kulttuureissa antaa mahdollisuuden hyödyntää välinettä eri tarkoituksiin. Tutkimuksessa sitä voi hyödyntää esimerkiksi testaamalla sitä edelleen muiden mittarien, kuten puheviestintäkompetenssin mittarien kanssa, jotta ymmärrettäisiin kuuntelutaitojen suhteita muihin puheviestinnän taitoihin. Puheviestintäkoulutuksenkin tarpeisiin keskustelukuuntelun kapasiteettitesti tuo uutta tietoa. Kuuntelukapasiteettierojen ymmärtäminen voi antaa kouluttajille keinoja auttaa esimerkiksi niitä, joiden kuuntelukyky on syystä tai toisesta puutteellinen tai toisaalta keinoja kouluttaa niitä, joiden työtehtävät vaativat aivan erityisen hyvää kuuntelutaitoa.

\section{KIRJALLISUUS}

Aro, M. \& Wimmer, H. 2003. Learning to read: English in comparison to six more regular orthographies. Applied Psycholinguistics 21, 621-635.

Baddeley, A. D. 1986. Working memory. New York: Oxford University Press.

Baddeley, A. D. 2000. The episodic buffer: A new component of working memory? Trends in Cognitive Sciences 4 (11), 417-423.

Baddeley, A. D. 2001. Is working memory still working? American Psychologist 56 (11), 851-857.

Baddeley, A. D. 2003. Working memory and language: An overview. Journal of Communication Disorders 36 (3), 189-208.

Baddeley, A. D. \& Hitch, G. J. 1974. Working memory. Teoksessa G. H. Bower (toim.) The psychology of learning and motivation: Advances in research and theory 8. New York: Academic, 47-89.

Barker, L., Edwards, R., Gaines, C., Gladney, K. \& Holley, F., 1980. An investigation of proportional time spent in various communication activities by college students. Journal of Applied Communication Research, 8, 101-109.

Barker, L. L. \& Watson, K. W. 2000. Listen up. How to improve relationships, reduce stress, and be more productive by using the power of listening. New York: St. Martins Press.

Bentley, S. C. 1993. Listening and memory. Teoksessa A. D. Wolvin \& C. G. Coakley (toim.) Perspectives on listening. Norwood: Ablex, 78-105.

Berlo, D.K.,1960. The process of communication. New York: Holt, Rinehart and Winston. 
Bostrom, R. N. 1990. Listening behavior: Measurement and application. New York: Guilford.

Bostrom, R. N. 1996. Memory, cognitive processing, and the process of "listening": A reply to Thomas and Levine. Human Communication Research 23 (2), 298-305.

Brownell, J. 1999. Should Listening be Part of the Communication Discipline? Trends in Listening Theory, Research, and Training. Paper presented at the meeting of the National Communication Association, Chicago, Illinois.

Comrie, B. 1989. Language universals and linguistic typology. $2^{\text {nd }} \mathrm{ed.}$ Oxford: Blackwell.

Daneman, M. 1991. Working memory as a predictor of verbal fluency. Journal of Psycholinguistic Research 20, 445-464.

Daneman, M. \& Carpenter, P. A. 1980. Individual differences in working memory and reading. Journal of Verbal Learning and Verbal Behavior 19, 450-466.

Daneman, M. \& Carpenter, P. A. 1983. Individual differences in integrating information between and within sentences. Journal of Experimental Psychology: Learning, Memory, \& Cognition 9, 561-584.

Daneman, M. \& Green, I. 1986. Individual differences in comprehending and producing words in context. Journal of Memory and Language 25, 1-18.

Daneman, M. \& Merikle, P. M. 1996. Working memory and language comprehension; A meta-analysis. Psychonomic Bulletin and Review 3 (4), 422-433.

Davis, D., 2001. Two ears and one mouth: Two eyes and one hand. ILA Listening Post (summer), 77, 10-13.

Emmert, P., Emmert, V. \& Brandt, J. 1993. An analysis of male-female differences on the listening practices feedback report. Journal of the International Listening Association, 7, 43-55.

Fitch-Hauser, M. 1990. Making sense of data: Constructs, schemas, and concepts. Teoksessa R. Bostrom (toim.) Listening behavior. Measurement and application. New York: Guildford Press, 76-90.

Fitch Hauser, M. \& Hughes, M. A. 1988. Defining the cognitive process of listening: dream or reality? The Journal of the International Listening Association 2, 75-88.

Goby, V.P., \& Lewis, J.H., 2000, June. The key role of listening in business: A study of the Singapore insurance industry. Business Communication Quarterly, 63, 2, 4151.

Haarman, H. J., Davelaar, E. J. \& Usher, M. 2003. Individual differences in semantic short-term memory capacity and reading comprehension. Journal of Memory and Language 48 (2), 320-346,

Hallintolaki 434/2004).

Halsband, U., Krause, B. J., Sipilä, H., Teräs, M. \& Laihinen, A. 2002. PET studies on the memory processing of word pairs in bilingual Finnish-English subjects. Behavioural Brain Research 132, 47-57.

Janusik, L. A. 2003. Conversational listening span: a proposed measure of conversa- 
tional listening. Paper presented at the International Listening Association conference, Stockholm, Sweden, July.

Janusik, L. A. 2004. Researching listening from the inside out: The relationship between conversational listening span and perceived communicative competence. Unpublished doctoral dissertation. University of Maryland at College Park.

Janusik, L. A., Ilomäki, I., Mäki, E. \& Välikoski, T.-R. 2004. Conversational Listening Span: comparative research in Finland and in USA. Paper presented in the $25^{\text {th }}$ annual Conference of International Listening Association in Fort Myers, Florida, April $14^{\text {th }}$.

Just, M. A. \& Carpenter, P. A. 1987. A psychology of reading and language comprehension. Boston: Allyn \& Bacon.

Just, M. A. \& Carpenter, P. A. 1992. A capacity theory of comprehension: Individual differences in working memory. Psychological Review 99, 122-49.

Kuhn, T. S. 1963. The structure of scientific revolutions. $3^{\text {rd }}$ ed. Chicago: University of Chicago Press.

Laine-Sveiby, K., 1987. Kansallinen kulttuuri strategiana. Suomi ja Ruotsi - eroja ja yhtäläisyyksiä. Elinkeinoelämän valtuuskunta, Helsinki.

Lehtonen, J. 1993. Suomalaisuus, Suomi-kuva ja kansainvälistymisen haasteet. Teoksessa J. Lehtonen (toim.) Kulttuurien kohtaaminen. Näkökulmia kulttuurienväliseen kanssakäymiseen. Jyväskylä. Jyväskylän yliopiston viestintätieteiden laitos.

Lehtonen, J. \& Sajavaara, K. 1985. The silent Finn. Teoksessa D. Tannen \& M. Saville-Troike (toim.) Perspectives on Silence. Norwood: Ablex, 193-201.

Linnakylä, P., Malin, A., Blomqvist, I. \& Sulkunen, S. 2000. Lukutaito työssä ja arjessa. Aikuisten kansainvälinen lukutaitotutkimus Suomessa. Jyväskylän yliopisto. Koulutuksen tutkimuslaitos.

Mikkola, L. 2000. Supportiivinen viestintä hoitotyössä. Sosiaalisen tuen tutkimusnäkökulmien tarkastelua. Jyväskylän yliopisto. Viestintätieteiden laitos. Lisensiaatintutkimus.

Miller, G. A. 1956. The magical number seven, plus or minus two: Some limits of our capacity for processing information. Psychological Review 63, 81-97.

Miller, G. A. 1994. The magical number seven, plus or minus two: Some limits on our capacity for processing information. Psychological Review 101 (2), 343-352.

Miyake, A. \& Shah, P. (toim.) 1999. Models of working memory: Mechanisms of active maintenance and executive control. Cambridge: Cambridge University Press.

Morris, N. \& Sarll, P. 2001. Drinking glucose improves listening span in students who miss breakfast. Educational research 43 (2), 201-207.

Nyfors, R. 1995. Puheviestintää ja ilmaisutaitoa kehittämään. Opas äidinkielen ja suullisen ilmaisun testin ja arvioinnin järjestämiseen peruskoulun päättöluokilla. Helsingin yliopisto. Studia pedagogica 6 .

Pajunen, A. \& Palomäki, U. 1984. Tilastotietoja suomen kielen rakenteesta 1. Kotimaisten kielten tutkimuskeskuksen julkaisuja 30. Helsinki. 
Rhodes, S. C. 1993. Listening: A relational process. Teoksessa A. D. Wolvin \& C. G. Coakley (toim.) Perspectives on listening. College Park: Ablex, 217-240.

Roberts, C. V. 1988. The validation of listening tests: Cutting the Gordian knot. International Journal of Listening 2, 1-19.

Roberts, C. V. \& Vinson, L. 1998. Relationship among willingness to listen, receiver apprehension, communication apprehension, communication competence, and dogmatism. International Journal of Listening 12, 40-56.

Rubin, R. B. 1982. Assessing speaking and listening competence at the college level: the communication competency assessment instrument. Communication Education $31,19-32$.

Sallinen-Kuparinen, A. 1986. Finnish communication reticence. Perceptions and selfreported behaviour. Jyväskylän yliopisto. Studia Philologica Jyväskyläensia 19.

Steil, L.K., 1997. Listening training: The key to success in today's organization. In M.Purdy \& D.Borisoff (Eds.)Listening in everyday life: A personal and professional approach ( $2^{\text {nd }}$ ed.) (pp. 212-237). Lanham, MD: University Press of America.

Steinbrecher, M. M. \& Willmington, S. C. 1997. The Steinbrecher-Willmington Listening Test. $2^{\text {nd }}$ ed. Oshkosh: University of Wisconsin.

Suomen Hallitusmuoto 94/1919; $\$ 10$, perusoikeudet.

Thomas, L. T. \& Levine, T. R., 1994. Disentangling listening and verbal recall. Human Communication Research, Sep 94, Vol 21, (1), 103-129.

Thomas, L. T. \& Levine, T. R. 1996. Further thoughts on recall, memory, and the measurement of listening: A rejoinder to Bostrom. Human Communication Research 23 (2), 306-308.

Tiuraniemi, J. 2004. Esimiestyö ja sosioemotionaaliset ongelmat työyhteisössä. Hallinnon Tutkimus 3, 61-69.

Työturvallisuuslaki 738/2002; $\$ 10$.

Valkonen, T. 2001. Lukiolaisten kommunikaatiovalmiudet. Lukion 2. vuoden opiskelijoiden kommunikaatiovalmiulssien kansallinen arviointi 2000. Helsinki: Opetushallitus.

Valkonen, T. \& Mikkola, L. 2000. Miten analysoida tehtäväkeskeisen ryhmän vuorovaikutusta? Teoksessa M. Valo (toim.) Nykytietoa puheviestinnän opetuksesta. Jyväskylän yliopisto. Viestintätieteiden laitoksen julkaisuja 20, 86-108.

Vilkuna, M. 2001. Miten erilainen suomen kieli on? Teoksessa T. Rydman (toim.) Tiede ja elämä. Tieteen päivät. Tieteellisten seurain valtuuskunta. Osoitteessa http://www.kotus.fi/tutkimus/kielioppi/miten_erilainen.shtml. Viitattu maaliskuu 2004.

Välikoski, T.-R. 2000. Todistajana rikosoikeudenkäynnissä. Selvitys rikosoikeudenkäynnin viestinnällisestä luonteesta todistajan näkökulmasta. Tampereen yliopisto. Puheopin laitos. Raportteja 1/2000.

Välikoski, T.-R. 2004. The Criminal Trial as a Speech Communication Situation. Tampereen yliopisto. Acta Universitatis Tamperensis 1011. 
Waters, G. S. \& Caplan, D. 1996. Processing resource capacity and the comprehension of garden path sentences. Memory \& Cognition 24 (3), 342-355.

Watson, K. W. \& Barker, L. L. 2000. Watson/Barker Listening Test. $2^{\text {nd }}$ ed. New Orleans: Spectra.

Wheeless, L. R. 1975. An investigation of receiver apprehension and social context dimension of communication apprehension. The Speech Teacher 24, 261-265.

Whitney, P., Ritchie, B. G. \& Clark, M. B. 1991. Working-Memory capacity and the use of elaborative inferences in text comprehension. Discourse Processes 13, 133-145.

Wolvin, A.D., \& Coakley, C.G., 2000. Listening education in the $21^{\text {st }}$ century. International Journal of Listening, 14, 143-152. 